\title{
NURSING IN MISSION STATIONS
}

\author{
Miss Emana II. Higgiss, R. N., of the American Chureh Mission in
} Wuchang, China, writes of her work in the Klizabeth Bunn Memorial Hospital :

Two years have been spent in stndying Chinese, preparing to teach the pupil nurses in their own language. Our sehool will not be open before Christmas. The Wegleyan Mission his a very good training sclool and their experience has been most encouraging. Their murses are much liked by the doctors and foreigners for whom they nurse, they are gentle, eapable, and cxact, making very good private nurses. All they need is some one to train them thoroughly. The Chinese young women are just berinning to appreciate the opening which gives them independence, but doetors and nurses are rery few, they come out slowly, and for lack of these, hospitals eannot be opened and work does not enlarge. It is an intensoly interesting field and a work that will go on long after we ale dead. along with the schools of western melicine which are opening. It is quite worth the sacrifice of lenving home. There is no other sacrifice, for we have houses, food and elothes, just as at home. The elimate of this Yantstse Valley is not bad, with reasonable eare and a willinguess to take adviec. 1)uring the hottest and worst months of the summer, July and Iligust, we have two months in the mountains,

This is not a plea for nurses for onr own Episcopal Mrission alone. Every denomination is calling for nurses for its unission stntions, but we want those who ean teach others to nurse, so that the Chinese nurses will be started riglt, ready for the time when they dewide to depend on themselves instead of on the foreigner.

Renders of this department will he interested in seeing among the marringe announcements on another pigre. that of Miss Maddock, of Wuhu, China, to Dr. Ilart, of the same place, whose assistant she has been and will contime to be.

Our most recent news from Wuluu is as follows:

The idea of trainimg hoys ats nurses is growing populat $r$ and we can choose much better now. Two days ago a youth appeared asking to be trained. He gave his age as twenty-five, on being told that he was too old he shifted to seventeen. This brought a decidedly negative reply, as we told him there was no room for prevarieators. Nothing daunted he returned yesterday with a huge red and white enrelope enclosing a letter from a former minister to the United States from China. He discovered to his regret that influence does not weigh against honesty.

The water problem is a constant one liere, and probably the tea habit saves millions of lives cvery year, as it insures the boiling of water. A missionary 
friend telling her ehildren the story of Ishmael and Hagar tried to make the finding of the spring the climax. It fell on unsympathetie cars however, as the little ones suspecting this to be but the irony of fate exclaimed, "But they had no filter."

Our most pressing need is the fitting out of a laboratory for Doctor Hough. ton to earry on hacteriologieal work. That there is a vast unworked field here, medieal men at liome thoroughly realize. The eause and prevention and eure of many of the clieaded oriental diseases is to be discovered very largely in the mission hospital laboratory. The lanimu Canal zone has been robbed very largely of its terrors by the man with the nicroscope. Who can say what the bacteriologist will do for China's, and because of our intimacy, for Anerica's safety? Five liundrel dollars invested in seientifie rese'areh may reap an inealenlable harvest.

From a presonal letter reeeived from Miss Whitely, who is stationed at Porto Rico in a Presbyterian Mission Hospital, we make the following extraets of general interest:

It is not nceessary to tell you that a lospital is a lusy place; it is always so here, and there are dillienlties to eontend with thint are a little different from those in hospitals at home. The laek of perseverance and ambition are two of them, found in both nurses and servants. I have just returned from a two wecks' tour of the island and after seeing sone of the hones of these two elasses of people, I marvel that they are ever trained to be anything.

There are three American nurses here. Miss Ordway, the supcrintendent, las tauglit in mission schools on the island and in Mexien, so she is well acquainted with the language and claracteristies of the people, which it not only a great help to her but to the rest of us. We lave only one text-book in Spanish and that is an anatomy and physiology. It is cliflicult to get nany desirable applicants for the school. Some are mable to take any sort of a course, for they lark even ordinary intelligenee, others lare proved morally unfit. At present the class is more promising. Althougl the students are sometimes unreliable and very exasperating, one eannot liclp growing fond of them, for they are very kind and affectionate as well as high strung and passionate. One of the nurses finished a two y'ar' course in July and another will eome to the end of her time in January. After that there will be a long period before another class will go. They have never had any examinations or anything made of their graduation, so later we are going to have a little reception that the others may have something to look forward to.

All speak Spanish exeept two, so the work lias not been easy, trying to teach them with the little Spanish we have acquired and with a poor interpreter.

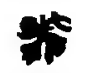

"No marvel Christmas lives so long;

He never knew but merry hours." 